\title{
EVALUASI UNIT BIOFILTER ANAEROB SISTEM INSTALASI PENGOLAHAN AIR LIMBAH (IPAL) RUMAH SAKIT IBU DAN ANAK (RSIA) ANUGERAH BUNDA KHATULISTIWA KOTA PONTIANAK
}

Rachmat Dyanto ${ }^{1)}$ Winardi Yusuf ${ }^{1)}$ Kiki Prio Utomo ${ }^{1)}$

${ }^{1)}$.Program Studi Teknik Lingkungan Jurusan Teknik Sipil Fakultas Teknik Universitas Tanjungpura, Pontianak Email : rachmatdyanto.rd@gmail.com

\begin{abstract}
ABSTRAK
Rumah sakit merupakan salah satu sarana dan prasarana yang dalam proses pengoperasiannya menghasilkan limbah. Air limbah yang dihasilkan dari rumah sakit memiliki potensi yang dapat mencemari lingkungan apabila baku mutu yang dihasilkan belum memenuhi standar yang ditetapkan. Agar baku mutu air limbah dapat tercapai, maka diperlukan suatu teknologi yang berfungsi untuk mengolah air limbah. Teknologi tersebut dikenal dengan istilah IPAL (Instalasi Pengolahan Air Limbah). Penelitian ini bertujuan untuk mengevaluasi unit IPAL khususnya unit biofilter anaerob dan memberikan rekomendasi alternatif pengolahan IPAL yang sesuai untuk mengolah air limbah yang dihasilkan dari Rumah Sakit Ibu dan Anak (RSIA) Anugerah Bunda Khatulistiwa. Pada penelitian ini dilakukan evaluasi terhadap IPAL berdasarkan aspek kinetika proses yang meliputi rasio nilai F/M, kuantitas dan keberagaman jenis bakteri pendegradasi pada unit biofilter anaerob. Berdasarkan hasil penelitian diperoleh hasil terdapat 2 genus bakteri pendegradasi yang terdapat di dalam air limbah yaitu Bacillus $s p$. dan Stapylococcus sp. sehingga diharuskan dilakukan penambahan konsorsium dengan keberagaman jenis bakteri yang beragam. Sistem pengolahan yang dilakukan pada IPAL RSIA Anugerah Bunda Khatulistiwa hanya menerapkan sistem pengolahan dengan biofilter anaerob yang menyebabkan air hasil olahan IPAL belum memenuhi standar baku mutu, sehingga diperlukan adanya penambahan unit proses berupa penambahan proses aerob yang dikombinasikan menjadi biofilter anaerob-aerob agar air limbah hasil olahan dapat memenuhi standar baku mutu lingkungan menurut Kepmen LH No. KEP58/MENLH/12/1995.
\end{abstract}

Kata Kunci - Bakteri, Biofilter Anaerob, IPAL, Konsorsium, Rasio F/M.

\begin{abstract}
Hospital is one of infrastructure in which its operation process produces waste. Wastewater generated in hospitals has potential that can pollute the environment if the set of quality standards does not meet the standards yet. In order to achieving wastewater quality standards, we need a technology which is used to treat wastewater. The technology is known as WWTP (Wastewater Treatment Plant). This study aimed to evaluate the WWTP unit particularly in anaerobic biofilter units and provide alternative recommendation of WWTP in which was suitable to treat wastewater generated from Mother and Child Hospital (MCH) Anugerah Bunda Khatulistiwa. In this study, an evaluation of the WWTP was based on kinetic aspect of the process including the ratio of the value of $F / M$, the quantity, and the diversity of degrading bacteria in anaerobic biofilter unit. Based on the result, there were two genus degrading bacteria contained in wastewater which were Bacillus sp. and Stapylococcus sp in which required addition of consortium with the plurality of diverse types of bacteria. Processing system done by the hospital was only applying treatment system with anaerobic biofilter that caused the processed water of WWTP did not meet the quality standard, leading to the need for additional unit process of additional aerobic process combined into anaerobic-aerobic biofilter for the waste water to meet the quality standard of environment according to Kepmen LH No. KEP-58/MENLH/12/1995.
\end{abstract}

Key Words - Bacteria, Anaerobic Biofilter, Consortium, Ratio F/M 


\section{PENDAHULUAN}

Rumah Sakit Ibu dan Anak (RSIA) Anugerah Bunda Khatulistiwa adalah salah satu rumah sakit swasta di Kecamatan Pontianak Tenggara Kota Pontianak yang memiliki Instalasi Pengolahan Air Limbah (IPAL) yang menerapkan sistem pengolahan dengan kombinasi pengolahan secara fisika dan biologi. IPAL pada rumah sakit ini menerapkan sistem pengolahan fisika berupa pengendapan dan pengolahan biologi dengan menggunakan biofilter anaerob. IPAL ini berfungsi untuk mengolah air limbah yang dihasilkan dari kegiatan medis seperti operasi dan kegiatan non medis berupa limbah aktivitas laundry.

Berdasarkan hasil uji kualitas effluent air limbah yang dilakukan oleh pihak rumah sakit pada bulan Desember tahun 2014, diketahui bahwa air limbah yang dihasilkan memiliki karakteristik nilai BOD $165 \mathrm{mg} / \mathrm{L}$, COD $465 \mathrm{mg} / \mathrm{L}$, TSS $159 \mathrm{mg} / \mathrm{L}$, dan NH3 20,7 mg/L. Berdasarkan Kepmen LH No. KEP-58/MENLH/12/1995 parameter tersebut belum memenuhi standar baku mutu yang telah ditetapkan. Menurut Eckenfelder, et.al (1988), terjadi hal seperti ini dikarenakan kesalahan pada proses pengolahan biologi seperti pemilihan sistem pengolahan yang kurang tepat dan kinerja unit biofilter anaerob yang kurang optimal. Kinerja unit biofilter anaerob dapat diketahui berdasarkan nilai $\mathrm{F} / \mathrm{M}$, efisiensi pengolahan dan kelimpahan jenis bakteri pendegradasi di dalamnya. Oleh sebab itu perlu dilakukan penelitian berupa evaluasi terhadap kemampuan IPAL dalam mengolah air limbah di rumah sakit, yang meliputi evaluasi pada aspek kinetika proses yang berlangsung di dalam unit IPAL. Penelitian ini berguna untuk mengetahui efisiensi pengolahan IPAL, dan alternatif pengolahan IPAL yang sesuai untuk mengolah air limbah. Sehingga kualitas air limbah yang dihasilkan dapat memenuhi standar baku mutu lingkungan.

\section{TINJAUAN PUSTAKA}

\section{A. Definisi Limbah dan Limbah Rumah Sakit}

Berdasarkan UU RI No.23 Tahun 1997, limbah adalah sisa suatu usaha atau kegiatan. Limbah merupakan buangan dalam bentuk zat cair yang mengandung bahan berbahaya dan beracun yang karena sifat dan konsentrasi maupun jumlahnya baik secara langsung maupun tidak langsung, dapat mencemari atau merusak lingkungan hidup, dan membahayakan lingkungan, kesehatan, dan kelangsungan hidup manusia serta makhluk hidup lainnya. Hampir semua kegiatan manusia akan menghasilkan limbah cair, termasuk kegiatan industrialisasi.

Menurut Permenkes RI No.12/04/Menkes/SK/X/2004, limbah rumah sakit yaitu semua limbah yang dihasilkan dari kegiatan rumah sakit dalam bentuk padat, cair dan gas yang mengandung mikroorganisme patogen, bahan kimia beracun dan radioaktivitas.

\section{B. Standar Baku Mutu Limbah Cair Rumah Sakit}

Pengukuran baku mutu limbah rumah sakit berdasarkan Keputusan Menteri Lingkungan Hidup Nomor 58 tahun 1995 tentang baku mutu limbah cair bagi kegiatan rumah sakit dalam Tabel 1 (Kepmen LH No.58/12/1995) sebagai berikut: 
Tabel 1. Baku Mutu Limbah Cair Bagi Kegiatan Rumah Sakit

\begin{tabular}{|c|c|}
\hline PARAMETER & $\begin{array}{c}\text { KADAR } \\
\text { MAKSIMUM }\end{array}$ \\
\hline FISIKA & $\leq 30^{\circ} \mathrm{C}$ \\
Suhu & \\
KIMIA & $30 \mathrm{mg} / \mathrm{L}$ \\
BOD $_{5}$ & $80 \mathrm{mg} / \mathrm{L}$ \\
COD & $30 \mathrm{mg} / \mathrm{L}$ \\
TSS & $6-9$ \\
pH & $0,1 \mathrm{mg} / \mathrm{L}$ \\
$\mathrm{NH}_{3}$ Bebas & $2 \mathrm{mg} / \mathrm{L}$ \\
PO $_{4}$ & \\
MIKROBIOLOGI & 10000 \\
Bakteri E.colli & \\
\hline
\end{tabular}

\section{METODOLOGI PENELITIAN}

\section{A. Tempat dan Waktu Penelitian}

Penelitian ini akan dilaksanakan di RSIA Anugerah Bunda Khatulistiwa Kota Pontianak dan untuk pengujian sampel dilakukan di Workshop Teknik Lingkungan dan Laboratorium Fakultas MIPA Universitas Tanjungpura, waktu penelitian yang direncanakan dalam penelitian ini akan dilaksanakan pada bulan Maret 2015 hingga Juni 2015.

\section{B. Prosedur Penelitian}

Pada penelitian ini metode yang digunakan dalam pengambilan sampel air limbah adalah grab sampling yaitu sampel air yang diambil pada waktu yang tertentu untuk masing- masing titik yang telah ditentukan sehingga diharapkan dapat mewakili kondisi kualitas air limbah pada unit IPAL. Sampel air limbah yang telah diambil kemudian dilakukan serangkaian proses pada laboratorium. Berikut ini merupakan tahapan yang dilakukan pada proses penelitian:

- Sampling Air Limbah

Sampling air limbah dilakukan melalui metode Grab Sampling yaitu suatu sampel air yang diambil pada waktu yang tertentu untuk masing- masing titik yang telah ditentukan sehingga diharapkan dapat mewakili kondisi kualitas air limbah pada unit IPAL atau badan air secara keseluruhan. Sampel air limbah diambil dari bak penampungan air hasil pengolahan air limbah. Air limbah dimasukkan ke dalam jerigen plastik berukuran \pm 5 liter yang sebelumnya telah dicuci bersih dan dibilas dengan akuades, kemudian sampel limbah yang telah diambil diidentifikasi warna dan baunya. Selain itu, dianalisis $\mathrm{pH}$ dan suhu dari limbah tersebut.

- Penyiapan Media NA (Nutrient Agar)

Untuk membuat 1 liter medium NA Pronadisa, sebanyak 23 gram medium NA instan (Merk) dilarutkan dalam akuades dan volume akhirnya diatur sampai 1 liter. Campuran ini kemudian disterilkan dengan autoklaf pada tekanan $15 \mathrm{lbs}$ dan temperatur $121^{\circ} \mathrm{C}$ selama 15 menit. Medium yang sudah steril ini selanjutnya disimpan pada suhu $4^{\circ} \mathrm{C}$ sampai diperlukan. 
- Pengukuran MLSS (Mixed-liquor suspended solids)

MLSS diukur dengan cara menimbang padatan tersuspensi dalam air limbah yang kemudian dikeringkan pada suhu $105^{\circ} \mathrm{C}$ hingga kering dan kemudian ditimbang berat dari padatan tersebut. Dari hasil pengeringan padatan diperoleh berat MLSS sebesar $1 \mathrm{gram} / \mathrm{m}^{3}$, dan dari hasil tersebut kemudian dikonversi ke dalam satuan $\mathrm{kg} / \mathrm{m}^{3}$.

- Isolasi Bakteri

Isolasi bakteri dilakukan dengan menggunakan metode pengenceran dan pour plate. Sampel air limbah diambil sebanyak $1 \mathrm{ml}$ dan dimasukkan ke dalam tabung reaksi yang berisi $9 \mathrm{ml}$ aquades steril. Sampel dikocok sampai homogen dan dilakukan pengenceran berseri dari $10^{-1}$ sampai $10^{-7}$. Pada 4 pengenceran terakhir yaitu pengenceran $10^{-4}$ dan $10^{-7}$ selanjutnya dipipet sebanyak $0,1 \mathrm{ml}$ lalu dituangkan pada media NA (nutrient agar), lalu diinkubasi selama 24 jam atau hari. Bakteri yang tumbuh dari masing-masing sampel setelah diinkubasi selama 1 hari kemudian diseleksi lebih lanjut dengan menumbuhkan kembali secara bertahap dengan metode pour plate pada media NA (nutrient agar), diinkubasi pada suhu $37^{\circ} \mathrm{C}$ selama 48 jam. Selanjutnya dilakukan pemurnian koloni dengan metode gores kuadran hingga diperoleh koloni tunggal/terpisah. Koloni tunggal yang telah diperoleh diremajakan pada media agar miring dan diberi kode sesuai asal sumber sampel agar tidak tertukar dengan yang lain.

\section{Teknik Analisis Data}

Penentuan nilai Rasio F/M diperoleh melalui perhitungan dengan menggunakan rumus sebagai berikut:

$$
\text { Ratio F/M }(\mathrm{kgBOD})=\frac{Q \times\left(S_{0}-S\right)}{M L S S \times V}
$$

Keterangan:

$$
\begin{array}{ll}
\mathrm{Q} & =\text { Debit air limbah }\left(\mathrm{m}^{3} /\right. \text { hari) } \\
\mathrm{S}_{0} & =\mathrm{BOD} \text { inlet }(\mathrm{mg} / \mathrm{l}) \\
\mathrm{S} & =\text { BOD outlet }(\mathrm{mg} / \mathrm{l}) \\
\mathrm{MISS} & =\text { Mixed-liquor suspended solids }\left(\mathrm{kg} / \mathrm{m}^{3}\right) \\
\mathrm{V} & =\text { Volume reaktor IPAL }\left(\mathrm{m}^{3}\right)
\end{array}
$$

Penentuan jumlah koloni bakteri diperoleh melalui perhitungan dengan menggunakan rumus sebagai berikut:

$$
\text { Koloni per } m l=\text { jumlah } \text { koloni } x \frac{1}{\text { faktor pengenceran }}
$$

\section{HASIL DAN PEMBAHASAN}

\section{A. Karakteristik dan Kualitas Air Limbah RSIA Anugerah Bunda Khatulistiwa}

Air limbah yang dihasilkan RSIA Anugerah Bunda Khatulistiwa memiliki debit sebesar $3,5 \mathrm{~m}^{3}$ /hari. Air limbah tersebut berasal dari beberapa sumber seperti aktivitas laundry, dan aktivitas medis yang diolah di dalam IPAL. Dari hasil pengamatan di lapangan, diketahui bahwa effluen air limbah rumah sakit masih berbau tidak sedap dan bewarna abu-abu kehitaman. 
Menurut Keputusan Menteri Lingkungan Hidup Nomor 58 tahun 1995 hal ini mengindikasikan bahwa kualitas air limbah masih belum memenuhi standar kualitas air limbah yang ditetapkan. Berikut merupakan data kualitas air limbah sebelum dan sesudah melewati proses pengolahan yang ditunjukkan dalam Tabel 2.

Tabel 2. Data Kualitas Air Limbah Sebelum Proses Pengolahan

\begin{tabular}{|c|c|c|c|c|c|}
\hline \multirow{2}{*}{ No. } & \multirow{2}{*}{ Parameter } & \multirow{2}{*}{ Satuan } & Kadar & \multicolumn{2}{|c|}{ Hasil Pemeriksaan } \\
\cline { 4 - 6 } & & & Maksimum & Inlet IPAL & Outlet IPAL \\
\hline 1. & Suhu & ${ }^{\circ} \mathrm{C}$ & 30 & 26,4 & 26,5 \\
2. & $\mathrm{pH}$ & & $6,0-9,0$ & 6,96 & 6,91 \\
3. & $\mathrm{BOD}$ & $\mathrm{mg} / \mathrm{L}$ & 30 & 186 & 165 \\
4. & $\mathrm{COD}$ & $\mathrm{mg} / \mathrm{L}$ & 80 & 546 & 465 \\
5. & $\mathrm{TSS}$ & $\mathrm{mg} / \mathrm{L}$ & 30 & 81 & 159 \\
6. & $\mathrm{NH3}-\mathrm{N}$ & $\mathrm{mg} / \mathrm{L}$ & 0,1 & 8,12 & 20,7 \\
7. & $\mathrm{PO} 4$ & $\mathrm{mg} / \mathrm{L}$ & 2 & 1,61 & 1,78 \\
\hline
\end{tabular}

Ket : warna orange muda menunjukkan nilai parameter di atas baku mutu

\section{B. Analisis Rasio Nilai F/M pada IPAL RSIA Anugerah Bunda Khatulistiwa}

Rasio nilai F/M digunakan untuk mengetahui jumlah food atau substrat yang masuk ke dalam sebuah reaktor dibagi dengan jumlah massa atau mikroorganisme di dalam reaktor. Adapun untuk menghitung nilai F/M harus terlebih dahulu diketahui nilai MLSS (Mixed-liquor suspended solids). Selanjutnya setelah nilai MLSS telah diperoleh, dapat dihitung nilai F/M. Berikut ini merupakan data perhitungan mengenai rasio nilai $\mathrm{F} / \mathrm{M}$ yang ditunjukkan dalam persamaan sebagai berikut:

Diketahui:

$Q=3,5 \mathrm{~m}^{3} /$ hari

$$
M L S S=0,0001 \mathrm{~kg} / \mathrm{m}^{3}
$$

$S_{0}=186 \mathrm{mg} / \mathrm{l}$

$$
V=5 m^{3}
$$

$S=30 \mathrm{mg} / \mathrm{l}$

Maka untuk rasio nilai F/M dapat dihitung dengan cara sebagai berikut :

Ratio $\mathrm{F} / \mathrm{M}\left(\mathrm{kg} B O D_{5}\right)=\frac{Q x\left(S_{0}-S\right)}{M L S S \times V}$

Ratio F/M $=\frac{3,5 \mathrm{~m}^{3} / \operatorname{harix}(186 \mathrm{mg} / \mathrm{L}-30 \mathrm{mg} / \mathrm{L})}{0,0001 \mathrm{~kg} / \mathrm{m}^{3} \times 5 \mathrm{~m}^{3}}$

Ratio F/M $=\frac{\left.3,5 \mathrm{~m}^{3} / \text { hari } x \text { 0,000156 kg/m } \mathrm{m}^{3}\right)}{0,0001 \mathrm{~kg} / \mathrm{m}^{3} \times 5 \mathrm{~m}^{3}}=1 \mathrm{~kg} \mathrm{BOD}$

Nilai $\mathrm{F} / \mathrm{M}$ menyatakan perbandingan makanan terhadap mikroorganisme yang terdapat dalam bioreaktor. Nilai F/M yang disarankan untuk sistem pengolahan air limbah adalah 0,1-0,3 kg BOD/kg MLSS.hari (Nathanson, 1986). Hasil perhitungan untuk rasio $\mathrm{F} / \mathrm{M}$ yang didapatkan pada penelitian ini menunjukkan bahwa rentang nilai $\mathrm{F} / \mathrm{M}$ sebesar $1 \mathrm{~kg} \mathrm{BOD}_{5} /$ hari tidak sesuai dan melebihi rentang nilai 0.1-0.3 kg BOD/kg MLSS hari. 
Dari hasil perhitungan tersebut diketahui bahwa jumlah food atau makanan yang masuk memiliki jumlah yang lebih besar dibandingkan dengan massa/mikroorganisme yang terdapat di dalam air limbah yang mengakibatkan reaktor IPAL mengalami kelebihan makanan dan kekurangan bakteri pendegradasi sehingga efisiensi pengolahan pada IPAL menjadi kurang optimal. Oleh sebab itu, evaluasi yang dapat dilakukan untuk penanganan masalah ini adalah dengan cara menambahkan jumlah mikroorganisme melalui penambahan starter bakteri dengan jenis yang lebih beragam seperti efektif mikroorganisme. Selain itu, menurut Hammer (1986), dalam air limbah domestik rasio F/M yang optimum berkisar antara 0,2 - 0,5 kg BOD/kg MLSS.hari tetapi dapat lebih tinggi hingga 1,5 jika digunakan oksigen. Hal ini berarti bahwa untuk mencapai rasio F/M yang optimal pada proses pengolahan limbah harus dilakukan penambahan proses berupa penambahan perlakuan aerasi sehingga terbentuk proses aerob pada lingkungan reaktor IPAL.

Menurut Davis dan Cornwell (1991), nilai F/M yang tinggi (waktu tinggal lumpur aktif rendah) menyebabkan sistem kelebihan makanan. Keadaan ini menyebabkan efisiensi pengolahan menjadi buruk. Nilai F/M rendah (waktu tinggal lumpur aktif panjang) menyebabkan sistem kekurangan makanan, keadaan ini menghasilkan degradasi limbah yang lebih baik.

\section{Kuantitas dan Keragaman Jenis Bakteri Pendegradasi dalam Unit IPAL RSIA Anugerah Bunda Khatulistiwa}

Berikut ini merupakan data kuantitas koloni bakteri pendegradasi yang teridentifikasi dalam penelitian yang ditunjukkan pada Tabel 3.

Tabel 3. Data Kuantitas Koloni Bakteri

\begin{tabular}{|c|c|c|c|c|c|}
\hline & & \multicolumn{4}{|c|}{ Jumlah Koloni Bakteri } \\
No. & $\begin{array}{c}\text { Tingkat } \\
\text { Pengenceran }\end{array}$ & \multicolumn{4}{|c|}{} \\
\cline { 3 - 6 } & & Sp I & Sp II & SpIII & Sp IV \\
\hline 1. & $10^{-1}$ & TNTC & TNTC & TNTC & TNTC \\
2. & $10^{-2}$ & TNTC & TNTC & TNTC & TNTC \\
3. & $10^{-3}$ & TNTC & TNTC & TNTC & TNTC \\
4. & $10^{-4}$ & 40 & - & - & - \\
5. & $10^{-5}$ & 88 & 1 & - & - \\
6. & $10^{-6}$ & 32 & - & 1 & - \\
7. & $10^{-7}$ & 22 & 3 & 6 & 2 \\
\hline
\end{tabular}

Ket : TNTC (Too Numerous Too Count / terlalu banyak untuk dihitung)

Berdasarkan data pada Tabel 2 kemudian dilakukan perhitungan terhadap jumlah koloni bakteri yang terapat dalam 1 reaktor, untuk menghitung jumlah koloni yang terdapat di dalam reaktor IPAL dapat dihitung menggunakan rumus :

$$
\text { Koloni per } \mathrm{ml}=\text { jumlah koloni } \mathrm{x} \frac{1}{\text { faktor pengenceran }}
$$


Berikut ini adalah contoh menghitung jumlah koloni pada reaktor IPAL RSIA Anugerah Bunda Khatulistiwa dengan menggunakan data yang diperoleh dari hasil penelitian di laboratorium untuk spesies I. Perhitungan untuk jumlah koloni dalam reaktor IPAL dilakukan pada pengenceran $10^{-7}$ :

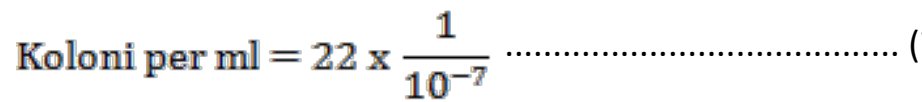

$$
\begin{aligned}
& \text { Koloni per } \mathrm{ml}=220000000 \mathrm{CFU} / \mathrm{ml}
\end{aligned}
$$

Hasil perhitungan tersebut kemudian dikonversi untuk menghitung jumlah koloni bakteri yang terdapat di dalam reaktor IPAL dengan mengalikan hasil yang diperoleh dengan volume reaktor IPAL. Sehingga jumlah koloni bakteri spesies I dalam reaktor IPAL adalah :

$$
\begin{aligned}
& \text { Volume IPAL }=5 \mathrm{~m}^{3} \text {, maka } \\
& \text { Koloni per reaktor }=220000000 \mathrm{CFU} / \mathrm{ml} \mathrm{x} 5 \mathrm{~m}^{3} \\
& \text { Koloni per reaktor }=220 \mathrm{CFU} / \mathrm{m}^{3} \times 5 \mathrm{~m}^{3} \\
& \text { Koloni per reaktor }=1100 \mathrm{CFU}
\end{aligned}
$$

Berikut ini data jumlah koloni bakteri berdasarkan spesies di dalam reaktor IPAL Tabel 4.

Tabel 4. Data Koloni Bakteri Dalam Reaktor IPAL

\begin{tabular}{|c|c|c|}
\hline No. & Kode Bakteri & Jumlah Bakteri Dalam Reaktor \\
\hline 1 & Sp I & 1100 CFU \\
2 & Sp II & 150 CFU \\
3 & Sp III & 300 CFU \\
4 & Sp IV & 100 CFU \\
\hline
\end{tabular}

Tabel 3 menunjukkan jumlah berbagai koloni bakteri dalam reaktor IPAL RS Anugrah Bunda dan terlihat jelas terdapat satu spesies bakteri yang mendominasi yaitu spesies I dengan jumlah koloni 1100 CFU (Coloni Form Unit). Menurut Atlas dan Bartha (1998), mikroba akan mampu hidup berdasarkan kemampuan bersaing dengan mikroba lainnya dalam memperebutkan nutrisi dan berdasarkan tipe dari nutrisi yang ada pada suatu lokasi, sehingga besar kemungkinan mikroba yang lebih cepat beradaptasi dapat lebih cepat tumbuh sebab lingkungan serta nutrisi sesuai dengan tempat asalnya. Banyaknya jumlah koloni bakteri khususnya bakteri spesies I disebabkan terbentuknya sel-sel bakteri baru dari pemanfaatan bahan organik oleh bakteri melalui proses konversi. Pembentukan sel-sel bakteri baru meningkatkan persaingan antar bakteri dalam memanfaatkan bahan organik. Penurunan bahan organik akibat proses dekomposisi dan kompetisi dalam memanfaatkan bahan organik menyebabkan penurunan jumlah koloni bakteri yang lain di dalam reaktor IPAL. Analisis ini didukung melalui penelitian Nainggolan (2009), yang menyatakan bahwa jumlah populasi mikroba yang meningkat dapat menimbulkan kompetisi antar mikroorganisme. Bentuk kompetisi ini dapat berupa kompetisi dalam merebut ruang, air, dan unsur-unsur hara. 
Selain data kuantitas bakteri, dalam penelitian ini juga dilakukan identifikasi terhadap morfologi dan genus bakteri pendegradasi yang terdapat di dalam IPAL RSIA Anugerah Bunda Khatulistiwa. Data morfologi dan keragaman jenis bakteri diperoleh dengan cara memurnikan masing-masing koloni bakteri yang pada akhirnya akan didapat sebuah koloni tunggal. Berikut data morfologi bakteri yang berhasil diidentifikasi dalam penelitian yang disajikan dalam Tabel $\mathbf{5}$.

Tabel 5. Data Morfologi Koloni Bakteri

\begin{tabular}{|c|c|c|c|c|}
\hline \multirow{2}{*}{$\begin{array}{c}\text { Kode } \\
\text { Bakteri }\end{array}$} & \multicolumn{4}{|c|}{ Identifikasi Bakteri } \\
\cline { 2 - 5 } & $\begin{array}{c}\text { Bentuk } \\
\text { Koloni }\end{array}$ & Tepian & Elevasi & Warna \\
\hline Sp I & Bulat & Rata & Cembung & Putih Susu \\
Sp II & Bulat & Rata & Cembung & Kuning \\
Sp III & Bulat & Rata & Cembung & Putih Kusam \\
Sp IV & Bulat & Rata & Datar & Putih Bening \\
\hline
\end{tabular}

Berdasarkan tabel di atas teridentifikasi 4 jenis bakteri pendegradasi. Spesies I, II, III memiliki karakteristik bentuk koloni bulat, tepian rata, elevasi cembung, dengan warna secara berurutan putih susu, kuning, dan putih kusam. Sedangkan spesies IV memiliki karakteristik bentuk koloni bulat, tepian rata, elevasi datar, dan warna putih bening. Berikut ini adalah gambar setiap jenis spesies bakteri yang teridentifikasi dalam penelitian:

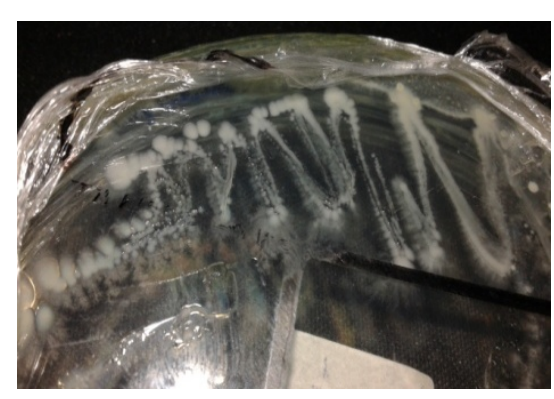

A. Spesies I

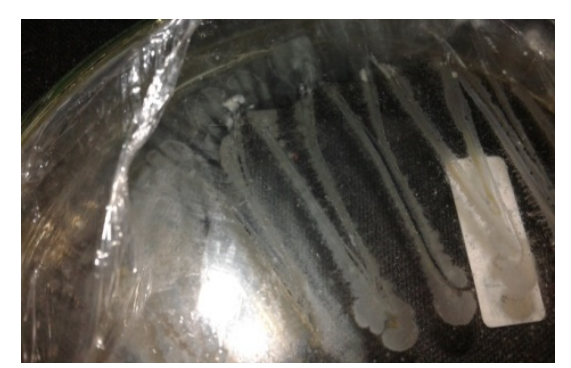

C. Spesies III

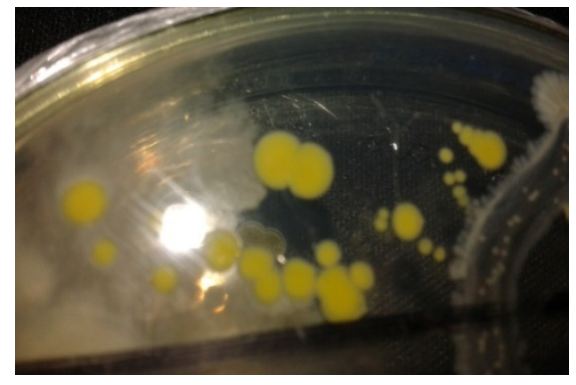

B. Spesies II

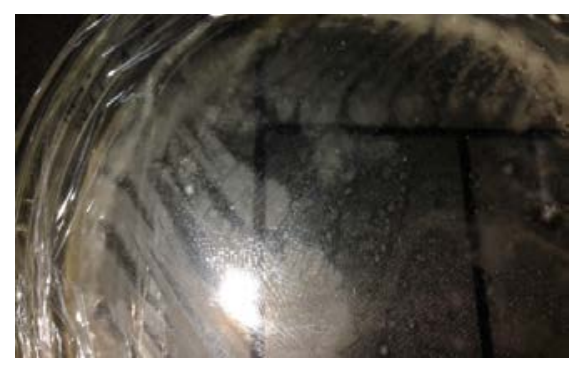

D. Spesies IV

Gambar 1. Morfologi Bakteri 


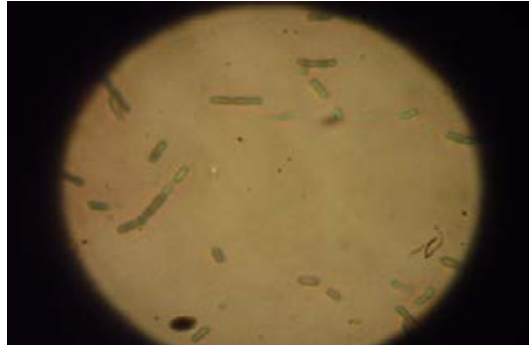

A. Spesies I

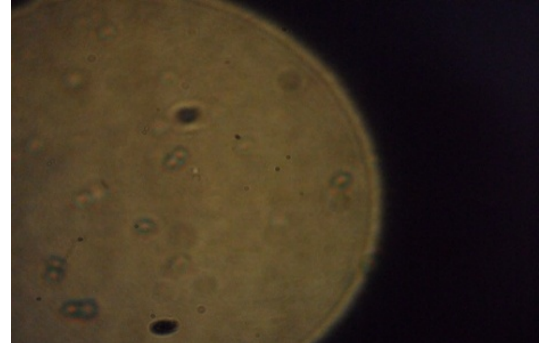

B. Spesies II

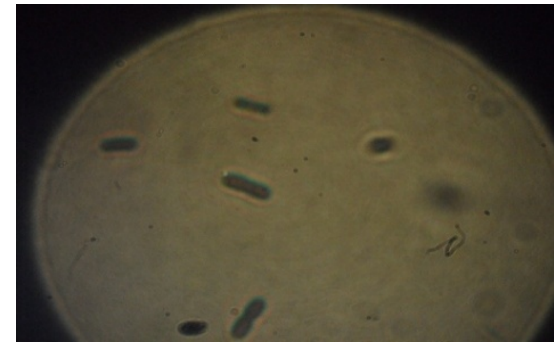

C. Spesies III

Gambar 5. Bentuk Sel Bakteri

Gambar 1 menunjukkan bentuk sel bakteri yang berhasil dimurnikan. Berdasarkan perlakuan pemurnian bakteri yang telah dilakukan, menunjukkan bahwa 4 dari spesies bakteri yang dapat ditemukan hanya 3 spesies saja yang berhasil dilakukan pemurnian. Hal ini dikarenakan bakteri dengan kode isolat spesies IV merupakan bakteri anaerob obligat yang tumbuh pada bagian bawah media NA (Nutrien Agar) yang tidak terdapat kandungan oksigen sehingga membuat langkah pemurnian menjadi sulit. Bakteri yang teridentifikasi sebagian besar berbentuk coccus (bulat) dan basil (batang).

Tiga jenis bakteri yang telah diidentifikasi dan dimurnikan kemudian dilakukan uji biokimia untuk mengetahui genus dari setiap jenis bakteri. Data identifikasi genus bakteri dapat dilihat pada Tabel 6.

Tabel 6. Data Identifikasi Genus Bakteri

\begin{tabular}{|c|c|c|}
\hline No. & Kode Bakteri & Genus Bakteri \\
\hline 1 & $\mathrm{Sp} \mathrm{I}$ & Bacillus sp. I \\
2 & $\mathrm{Sp} \mathrm{II}$ & Stapylococcus sp. \\
3 & $\mathrm{Sp} \mathrm{III}$ & Bacillus sp. II \\
\hline
\end{tabular}

\section{KESIMPULAN}

Berdasarkan penelitian yang telah dilakukan, maka kesimpulan yang diperoleh dari penelitian ini adalah sebagai berikut:

1. Hasil evaluasi pada unit biofilter anaerob menunjukkan bahwa rasio nilai F/M sebesar $1 \mathrm{~kg} \mathrm{BOD}_{5} /$ hariyang menandakan jumlah substrat yang masuk melebihi dari jumlah mikroorganisme yang terdapat dalam reaktor IPAL yang menyebabkan efisiensi pengolahan IPAL RSIA Anugerah Bunda Khatulistiwa menjadi kurang optimal. Ditemukan tiga jenis spesies bakteri konsorsium pada unit IPAL seperti bacillus sp.l, bacillus $s p . I l$, dan staphylococcus $s p$. dengan genus bacillus $s p . l$ sebagai bakteri yang mendominasi, sehingga menyebabkan proses degradasi polutan dalam air limbah menjadi kurang optimal. 
2. Rekomendasi pengolahan yang dapat diberikan untuk meningkatkan kinerja unit IPAL RSIA Anugerah Bunda Khatulistiwa adalah dengan cara penambahan unit proses dalam sistem pengolahan berupa proses aerob dengan bantuan oksigen atau dengan mengkombinasikan proses pengolahan menjadi proses biofilter aerob-anaerob dan melakukan penambahan keberagaman jenis bakteri pendegradasi dengan cara menggunakan starter bakteri yang memiliki diversitas tinggi seperti Efektif Mikroorganismeagar air limbah yang dihasilkan dapat memenuhi standar baku mutu.

\section{UCAPAN TERIMAKASIH}

Dengan selesainya penelitian ini saya mengucapkan terima kasih yang sebesar-besarnya kepada Allah Swt, kedua orang tua, kedua dosen pembimbing yaitu Bapak Winardi Yusuf, ST., MT dan Bapak H. Kiki Prio Utomo, ST., MSc serta Ibu Aini Sulastri, S.Si., M.Si dan Ibu Jumiati, S.Si., M.Si dan tidak lupa saya ucapkan terima kasih kepada temanteman Teknik Lingkungan 2011 dan semua orang yang telah berperan dalam membantu penelitian yang tidak dapat di ucapkan satu persatu. Harapan saya penelitian ini dapat bermanfaat bagi semua dan dapat dipergunakan sebagaimana mestinya.

\section{DAFTAR PUSTAKA}

Atlas, R. M. dan Bartha, R. 1998. Microbial Ecology Fundamentals dan Applications. Benjamin Cummings Publishing Company Inc., California.

Davis, M.L. dan Cornwell. D.A. 1991. Introduction to Enviromental Engineering, McGraw Hill Book Co. Singapore.

Eckenfelder, W.W. 1988. Anaerobic Versus Aerobic Treatment In The USA.in: Anaerobic Digestion. Pergamon Press New York.

Hammer, M.J. 1986. Water and Wastewater Technology, SI Version. John Wiley \& Sons : New York.

Keputusan Menteri Negara Lingkungan Hidup Republik Indonesia, Nomor : KEP58/MENLH/12/1995 Tentang Baku Mutu Limbah Cair Bagi Kegiatan Rumah Sakit.

Keputusan Menteri Kesehatan Nomor : 1204/MENKES/SK/X/2004 tentang Persyaratan Kesehatan Lingkungan Rumah Sakit, Jakarta: Departemen Kesehatan.

Nainggolan, J. 2009. Kajian pertumbuhan Bakteri Accetobacter sp. dalam KombuchaRosela Merah (Hibiscus sabdariffa) pada Kadar Gula dan Lama Fermentasi yang Berbeda. (Tesis). Medan : Universitas Sumatera Utara.

Nathanson, J.A. 1986. Basic Environmental Technology : Water Supply, Waste Disposal, and Pollution Control. John Wiley \& Sons, Inc. New York. 